\title{
Historical theology at public universities matter
}

\begin{tabular}{|c|c|}
\hline $\begin{array}{l}\text { Author: } \\
\text { Jerry Pillay }{ }^{1}\end{array}$ & \\
\hline $\begin{array}{l}\text { Affiliation: } \\
{ }^{1} \text { Department } \\
\text { History and } \mathrm{Ch} \\
\text { Faculty of The } \\
\text { University of } \\
\text { South Africa }\end{array}$ & $\begin{array}{l}\text { f Church } \\
\text { urch Polity, } \\
\text { ology, } \\
\text { retoria, }\end{array}$ \\
\hline $\begin{array}{l}\text { Research Proj } \\
\text { Project Leade } \\
\text { Project Numb }\end{array}$ & $\begin{array}{l}\text { ct Registration: } \\
\text { e. J. Pillay } \\
\text { er: } 04653484\end{array}$ \\
\hline $\begin{array}{l}\text { Description: } \\
\text { This research } \\
\text { project, 'Africa } \\
\text { and Developm } \\
\text { by Prof. Dr Jer } \\
\text { Department } \\
\text { History and Ch } \\
\text { Faculty of The } \\
\text { University of P }\end{array}$ & $\begin{array}{l}\text { s part of the } \\
\text { n Christianity } \\
\text { ent', directed } \\
\text { ry Pillay, } \\
\text { f Church } \\
\text { lurch Polity, } \\
\text { ology, } \\
\text { retoria. }\end{array}$ \\
\hline $\begin{array}{l}\text { Correspondin } \\
\text { Jerry Pillay, } \\
\text { jerry.pillay@u }\end{array}$ & $\begin{array}{l}\text { gauthor: } \\
\text { o.ac.za }\end{array}$ \\
\hline $\begin{array}{l}\text { Dates: } \\
\text { Received: } 06 \text { S } \\
\text { Accepted: } 07 \\
\text { Published: } 20\end{array}$ & $\begin{array}{l}\text { ept. } 2017 \\
\text { Nept. } 2017 \\
\text { Nov. } 2017\end{array}$ \\
\hline $\begin{array}{l}\text { How to cite th } \\
\text { Pillay, J., } 2017 \\
\text { theology at pu } \\
\text { universities m } \\
\text { Teologiese Stu } \\
\text { Theological St } \\
\text { a4807. https:/ } \\
10.4102 / \text { hts.v }\end{array}$ & $\begin{array}{l}\text { is article: } \\
\text { 'Historical } \\
\text { blic } \\
\text { atter', HTS } \\
\text { dies/ } \\
\text { udies 73(1), } \\
\text { /doi.org/ } \\
73 i 1.4807\end{array}$ \\
\hline $\begin{array}{l}\text { Copyright: } \\
\text { (c) 2017. The } A \\
\text { Licensee: AOS } \\
\text { is licensed und } \\
\text { Creative Comr } \\
\text { Attribution Lic }\end{array}$ & $\begin{array}{l}\text { uthors. } \\
\text { S. This work } \\
\text { ler the } \\
\text { nons } \\
\text { ense. }\end{array}$ \\
\hline Read online: & \\
\hline 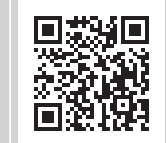 & $\begin{array}{l}\text { Scan this QR } \\
\text { code with your } \\
\text { smart phone or } \\
\text { mobile device } \\
\text { to read online. }\end{array}$ \\
\hline
\end{tabular}

South African universities are in the process of serious transformation and restructuring. The place of faculties of theology at universities has come under the spotlight resulting in the closure of several theological faculties or in the moving of theology to other faculties, mainly humanities or arts. Theology is under pressure, and in the current academic environment, church history, in its traditional form, has all but disappeared from South African universities. This article is an attempt to address the current situation. Although this article looks at the issue of theology at public universities, its main focus is to explore the future study of church history in the context of universities and, in particular, a Faculty of Theology. Understanding church history in the broad framework as historical theology, this article asserts the significance of church history at public universities, but points out the need to restructure the department giving due consideration to community engagement, internationalisation, transformation, Africanisation and interreligious collaboration. All of these would have a serious impact on teaching, learning and research.

\section{Introduction}

South African universities are in the process of serious transformation and restructuring. The place of theology faculties at universities has come under the spotlight resulting in the closure of several theological faculties or in the moving of theology to other faculties, mainly humanities or arts. Theology is under pressure, and in the current academic environment, church history, in its traditional form, has all but disappeared from South African universities. This article ${ }^{1}$ is an attempt to address this situation. Although I will deliberate on the issue of theology at public universities, my main focus is to outline a vision for the Department of Church History and Church Polity at the University of Pretoria. In order to do that I find it necessary to first ask and answer a few pertinent questions: What is a university? What is theology? Why should theology be at a public university? What is the meaning and value of history? An exploration of these questions would then lead me to the main focus of this article: the future study of church history in both the context of the university and, in particular, in the Faculty of Theology.

\section{What is a university?}

Already in 1858, President Henry Tappan (1961) of the University of Michigan wrote:

Of all mere human institutions there are none so important and mighty in their influence as Universities; because when rightly constituted, they are made up of the most enlightened, and the choicest spirits of our race; they embrace the means of all human culture, and they act directly upon the fresh and upspringing manhood [sic] of a nation. To them must be traced science, literature and art; the furniture of religious faith; the lights of industry; the moving forces of civilisation; and the brotherly unity of humanity. (p. 517)

The above quote indicates clearly that the purpose of the university has never been understood simply in terms of ideals for the internal life of the scholarly and teaching community. It embodies the ideal to make significant contributions to the well-being of the society as a whole. In other words, the purpose of the university is finally defined in relation to a vision of the good of society the concept of the common good (Griffin \& Hough 1991:98).

This idea of the common good was also embedded in the founding of the medieval universities. In this context, the university had two important relations to the common good. With respect to its own internal good, the university was to promote true piety by engaging in rational discourse uniting the love of God and the love of learning. This role was in itself important for the whole society. The second, more critical role, was to assist the ecclesiastical and political authorities to avoid excesses in a coordinated attempt to promote the common good of the whole social order (Ibid, p. 102).

1.This article was presented as an Inaugural Address at the University of Pretoria on 30 August 2017. 
In the transition to the modern university, we note some interesting changes. In the 15th century, the conflict between the Protestants and Catholics led to a growing dogmatism in both groups, and the impact on the universities was disastrous. In the 17th century, the relative autonomy of the great medieval universities collapsed. Protestants and Catholics insisted on confessional universities. It thus became apparent that the university was to serve only the common good of the church, and the transmission of the tradition was reduced to the transmission of religious orthodoxy (Ibid, p. 103). It is here that we note the transition to the modern university. Previously, at the university, all instruction had been based on the assumption that the truth was given and that the responsibility of the university was to transmit that unchanging truth to each generation. Now this was turned on its head. From that time until the present, the basic assumption of the modern university has been that truth is to be discovered by scientific investigation.

This new focus was to encourage a distancing from theology. The focus was upon a reasoned cultivation of the sense of the good and the true, not in the service of true piety, as before, but as the fruit of reason and for the sake of the development of the high culture (Ibid). There is a significant difference in the idea of the modern university: the primacy of research in the purpose of the university. University instruction had two purposes: To promote free communication of ideas generated by research in the various specialised sciences and to educate persons who would form a leadership class to clear worldview composed of the highest values of liberal culture. In this way, it was intended to provide an important service to the state as well but became captured often times by the ideology of political imperialism, as can be seen in the apartheid South Africa where some universities were used to propagate racism.

Universities today tend to continue to emphasise research, sometimes at the expense of teaching and learning which is equally important in knowledge creation and impartation. The problem is that most universities struggle to survive financially and so research has become the 'commercial product' of sustainability. Andrew Louth says that this undermines the idea of the university as a place of intellectual virtue and contemplation, as universities are being converted into educational businesses where academics must deliver and their produce must be marketable and subject to quality control (Louth 2004:69-79). Drawing on Newman's idea of the university (Newman 1982:74-92), Buitendag (2017) states that a university is not an institution but an idea. Knowledge is there for its own sake and purpose and the ideal of universal knowledge is its driving force. He adds that such an idea must be grounded in pragmatic research, economic demands, health sciences and ecological crisis. However, the driving forces of universities today are reputation, impact, success and funding.

The good news though is that given realities today have prompted a new trend in research that is relevant, dynamic and life-changing. Since Newman's time, the idea of a university has moved from the interpretation of reality to the transformation of reality (Duncan 2016, author's own italics). Research should be life-affirming and life-transforming, impacting the environment and world for the common good. This, for example, can be seen in the research direction of the Faculty of Theology. The Faculty has focused on Ecodomy (see 2016 Faculty Plan) which speaks about the fullness of life for all people. Research has to be relevant and directed to knowledge creation that impacts change.

In a recent address at the centenary dinner of the Faculty of Theology, David Ford captured well the purpose of a university in the changing world:

Universities are a remarkable global network of institutions that have multiplied during the past century and become increasingly important. They now play a leading role in global civilisation, educating most of those in positions of power and influence, and they are essential to the knowledge economy, the learning society, and the information age. They engage with most contemporary discourses, disciplines, technologies, industries, professions, institutions, and spheres of life in our world. (29 July 2017)

Ford asserts the role, significance and purpose of the university in knowledge creation, communication and connection as it seeks to link the various threads of life into a unified whole.

\section{What is theology?}

In responding to the question what is theology, Jonker (1976a:3-7) distinguishes four models of theology (see Naude 2015:297). These are (1) theology as mystical knowledge of God, constituting theology as 'wisdom' (Augustine and the Eastern Orthodox tradition); (2) theology as rational knowledge about articles of faith (Aquinas and Roman Catholic scholasticism); (3) theology as knowledge of God via revelation in Scripture (the Protestant tradition inaugurated by Luther and Calvin); and (4) theology as knowledge of God via human experience or religiosity (Schleiermacher, Neo-Protestant and Pentecostal theologies).

Maurice Wiles defines theology as 'reasoned discourse about God' (in Peel 2002:9). In this sense, he relegates theology to the whole church, not just the professional few. He argues that theology has become largely associated with the preparation of ordained ministers for churches, and it has thus become 'clericalised'. Over the years, theology has become 'professionalised' resulting in many different branches, which makes it even difficult for inter-disciplinary work within its own field let alone with other fields. The professionalisation of theology has led to its increasing 'secularisation'2 (Peel 2002:10).

Karl Barth (1975), drawing from Anselm, defines theology as 'faith in search of understanding' (Faith, Religion and the

'Secularization in the broadest sense is concerned with the interaction between Christianity and modernity. It can be defined as a process of mutual adjusteen Christianity and modernity. It can be defined as a process of mutual adjustment between the Christian tradition and its institutions on the one hand, and the socia forces of modernity on the other' (Avis 2003:52, also see Norris \& Inglehart [2004] for more about the sacred and secular). 
public university, p. 115). In simple terms, theology is about understanding God in life and context. It may not set out to 'explain' things in the way of natural science with outcomes of standardised procedures of experimental observations. Theology rather interprets in the manner of the human sciences (see Van Niekerk 2011:115). In this regard, theology has a hermeneutical function which is related to understanding. Understanding is transference of previously established meaning into another mental life. Theology is thus compelled to translate the Word of God as contained in the Scripture for present-day men, women and children. In the final analysis, to interpret and eventually understand is to not only try to establish the 'original meaning of the text', but also to make the life-world and experiences of the interpreter relevant to the meaning that the text may have for us here and now. Oden points out that we must be guarded to not move away from the original sources of Christianity: 'It is from the martyrs, saints, and prophets of Christian history, more than from recent riskless interpreters, that we learn of the value of classical Christianity' (Oden 1992:13; for more on theology, see also Oden 1979). For Gadamer (1975:273-274), to understand the same is necessarily to understand differently, that is, to understand in view of the changed circumstances and context of every new act of interpretation.

Writing in a similar way, Moltmann outlines three significant points that calls for the transformation of theology today. They are (1) theology's transition from the denominational to the ecumenical age, (2) the transition from the Eurocentric age to the age of humanity as a whole and (3) from the age of mechanistic domination of the world to the age of ecological worldwide community (Moltmann in Kung \& Tracy 1989:220-224). Against this background, Moltmann states further that Christian theology must be contemporary theology, in the positive sense of the word, and it must 'share the sufferings of this present time' with the whole creation. Christian theology must be identified as Christian. In every age, it must find its Christian identity anew. There must be the dialectical process of adjustment and reformation, relevance and identity (Ibid, p. 224).

There must be a hunger for wholeness. This must be seen in the work of the theologian who is expected to 'bring the learning and critical mentality of the academy to the faith community and the understanding of the faith community's needs and interests into the community of critical inquiry' (Marty in Kung \& Tracy 1989:198). This can be seen in the proponents of liberation, black and African Christian theologies and Public Theology - an attempt to make theology contextual, transformative and life-affirming. Theology is faith seeking understanding.

\section{Why should theology be at public universities?}

Right at the beginning, when the Western universities were born almost a thousand years ago, theology was the queen of sciences. Things changed, however, with the Enlightenment, when human reason stole theology's crown (Graham 2015:104). Today in the academy, theology is thus increasingly side-lined and marginalised. One is often confronted with the claim that theology has no real place in the academy; it is deemed less precise and less professional than the natural sciences, and it is being portrayed as irrational and irrelevant as it only presents grand narratives of the past. Not only is theology no longer the queen of the sciences, but it is facing the question whether it has any place at the university at all. Should this be the case? I shall now argue that theology should be at a public university for the following reasons:

Firstly, if theology does not qualify as a (natural) science that does not mean that it cannot play a significant role at the public university. In any case, Newman seriously disputes the claim that theology is not a science and should not be at the public university. The university, he says, is 'a place of teaching universal knowledge' (quoted in Gerrish 1993:251). Theology, he claims, is a 'branch of knowledge with as much right as astronomy to have a place in the university; it is the science of God, the truths we know about God put into a system' (Ibid, p. 252). University teaching without theology would accordingly be unphilosophical, lacking in wholeness. Newman pushes this a little further by stating that the science of God touches on so many other sciences; therefore, religious truth is not only a portion, but a condition, of general knowledge, and theology is, therefore, the highest and widest branch of knowledge - though it does not interfere with the freedom of secular science in its own department (lbid). The movie The Man Who Knew Infinity has a line that puts perspective on science and theology. The young mathematician, in the movie, says to his professor mentor who does not believe in God, 'no equation has any value if it cannot express something about God'.

It is interesting that even though Schleiermacher takes a somewhat different view from Newman in that he states that theology belongs to the church, yet he also agrees that 'science is the collective enterprise in which every researcher, in every field of inquiry, is engaged, and the fragments of knowledge that each contributes can be fully appreciated only in their relation to the whole' (Ibid, p. 255). There are many scholars and churches that believe that theology belongs to the church and should not be at universities. They, therefore, opt for their own theological schools and seminaries. However, in my opinion, this view provides a very limited view in reflecting, understanding, engaging and addressing the realities in the world. We can make a better impact when we understand and work with others to create a better life for all.

Secondly, David Ford makes a compelling argument as to why theology should be at public universities. He states that many universities are still stuck in the 20th century:

They are caught in a conception of the world that seems to take for granted an ideologically secular framework. For them modernity means moving in a linear way from a religious past to a secular future. They have not faced the fact that over $80 \%$ of the world's people are directly involved in some religion, or that, because of higher birth rates among the religious, this is likely to have increased by 2050 . Nor have they grasped that there are multiple modernities, some more religious, others less so. Nor do they take seriously that there are millions and millions of religious people who are highly 
educated in the sciences, the humanities, medicine, engineering, management, communications, and so on. Nor have they recognised that one of the great needs of our world is for thoughtful, intelligent, well-educated faith and belief, and for thoughtful, intelligent, welleducated understanding of faith and belief - whatever your own faith or belief (addressed on 29 July 2017 at the Centenary dinner of the Faculty of Theology, UP).

Further, Ford asserts that universities driven by the 20th century secularist mindset have not taken religions seriously. He outlines the short-sightedness of this in the following words:

This has not only meant that such universities are effectively blind, or at best one-eyed in relation to a huge dimension of human meaning and life, but it has also negatively affected public discourse about the religions and policy towards them, and It has contributed to the intellectual impoverishment of the religions themselves. (Ibid)

The point that Ford makes here is that we live in a religiously pluralistic world; this should be reason enough for theology to be in public universities.

Thirdly, in referring to the place of theology in universities in Africa, Joseph Mante states that Africa is a continent in which over $90 \%$ of the population is essentially religious in nature. He points out that if university education is to prepare people in Africa then it must engage with religions. He asserts that if this does not happen then education in Africa 'is a nonstarter; it will be useless; it will not prepare our young people to face society' (Mante 2017). In the context of Africa, 'God is and must be pre-eminent in all things, and that includes all knowledge; it includes all university education - whether biology or physics or chemistry or agriculture or business studies or engineering or medicine or what have you' (Ibid). Supporting the view of theology at the university, Abraham Kuyper argues that 'Sphere sovereignty' should be the hallmark of the university (Kuyper 1998:464). By this, Kuyper states that God is the ultimate Sovereign who possesses absolute sovereignty. Kuyper is emphatic that 'scholarship remains 'Sovereign in its own sphere' but serves both God and society'.

Fourthly, another significant reason for universities in Africa to give space and place to theological education is the knowledge that the centre of Christianity and other major religions is shifting to the Global South and, in particular, to Africa. According to the Pew Research Center, ${ }^{3}$ there were about 823 million people in sub-Saharan Africa in 2010, and this figure is expected to grow to 1.9 billion by 2050. Out of these figures, Christians are expected to grow from 517 million in 2010 to 1.6 billion in 2050, whereas Muslims are expected to increase from 248 million to 670 million in 2050. It is expected that by 2060 , an estimated $40 \%$ of all Christians in the world will be in sub-Saharan Africa, and $25 \%$ of all Muslims in the world would be living in sub-Saharan Africa. If this is true, then how can universities in Africa ignore the inclusion of theology or of religions at universities?
A fifth reason for theology at public universities is found in the need for ethical values and insight. The religious-ethical task of the university is twofold: firstly, it is to 'create understanding', and secondly, it needs to 'keep the flow of communication going' (Schlatter quoted by Brautigam in Graham 2015:110). Schlatter makes the case that the university is not a self-sufficient, isolated island. On the contrary, the university is organically integrated within the socio-cultural landscape, and all faculties, whatever their subject might be, influence society and culture in a distinct ethical way. In Schlatter's view, the work of the universities influences the [society's] present religious conditions. It does so in particular as it pursues the quest for truth, creating understanding and accumulating knowledge. Schlatter is adamant that ' $[e]$ very thought [at the university]' is guided by the canon of truth (Ibid, p. 111). And in its pursuit of truth, the university must ensure impartiality and openness to all different kinds of mindsets and movements. Let me illustrate this with an example. Some while ago church leaders were in a lecture where the lecturer was bragging about the new discoveries and probabilities that was going to change the course of nature. He stated that animals are cloned to perform functions and produce material that it was not designed to do in the first place. We then raised issues of a religious-ethical nature, to which he responded that he never thought about it in that way. This is precisely why we need theology at universities: to keep alive the ethical dimension.

Sixthly, Isabel Phiri and Sarojini Nadar in their article 'The Personal Is Political': Faith and Religion in a Public University (in Venter 2011:81-94) argue that faith and religion can and must be exposed to academic scrutiny and that the best place for such scrutiny is the public university. They further argue that closing down the study of religion and faith at universities will cause an increase in religious fundamentalism and promote life-denying instead of life-enhancing practices in religion. Christo Lombaard speaking against the a-religious impulses of modernity asserts the place of study of religion at the university from three perspectives: the paradigmatic philosophy of science, the sociological continuation of faith and the evolutionary importance of religion (in Venter 2011:49-65).

Having shown why theology should be at a public university, I now turn my attention to the aim of this article which is to cast a vision for church history or historical theology at the university. However, before I go there, it is necessary to first establish the meaning and value of history.

\section{The importance of history}

The South African Democratic Teachers Union (SADTU), in a paper entitled 'The importance of Teaching History as a Compulsory Subject ${ }^{\prime 4}$ wants the real South African history to be part of the curriculum as a compulsory subject in basic education. The claim is that South Africa lags behind other countries in terms of robust teaching of history as a subject 4.See http://www.sadtu.org.za/docs/disc/2014/history.pdf) 
that can help celebrate the heritage, culture and values that made South Africa as known today. ${ }^{5}$ The 2015 \#Rhodesmustfall protest also generated a further call to make history a compulsory subject at South African schools.

History ${ }^{6}$ is the subject that can help in social transformation, addressing the past, understanding the present and shaping the future. The Minister of Basic Education reiterated this call in 2015 stating in her speech in Parliament that 'we need to equip our youth with an accurate account of our history in order for them to make educated decisions regarding their own future' (Phakathi 2015). Although history is contentious and at times a controversial aspect of education, it has the potential to induct learners into educational, historical and cultural discourses that underpin society which can help students to learn about what constructed society in the past and how it impacts on the present and future. History is a discovery project providing information of the past and allowing for evaluation and analysis of the present and the shaping of the future. In this sense, history as a subject is necessary for both secondary and tertiary level. History as defined by the Department of Basic Education is:

\begin{abstract}
... the study of change and development in society over time. The study of history enables us to understand how past human action affects the present and influences our future, and it allows us to evaluate these effects. So, history is about learning how to think about the past, which affects the present, in a disciplined way. History is a process of enquiry. Therefore, it is about asking questions of the past: What happened? When did it happen? Why did it happen then? What were the short-term and longterm results? It involves thinking critically about the stories people tell us about the past, as well as the stories we tell ourselves. (Department of Basic Education 2011)
\end{abstract}

In asserting the need to study history, the Ministry of Education, nevertheless, points out the challenges that can be found within this discipline: It notes that:

History is a distinctive and well-established academic discipline with its own methods and discourses. Its field of study is potentially limitless, in that it encompasses the totality of past human experience. Among scholars who study history there can be differences and even controversy between some who regard it as an account of an actual past, and who view it as an entirely imagined of constructed past. (Ministry of Education 2000)

Drawing from the importance of history in schools and universities, I shall now validate the significance of church history at the university and, in particular, in the Faculty of Theology.

\section{Historical theology matters}

The University of Pretoria has taken as its slogan: 'Today matters'. In this same context, I would like to argue that church history matters at the university and in the Faculty of Theology. I pointed out earlier why theology should be

5.This claim is disputed because history is taught at schools until grade 7 at which point learners have to choose to study history.

6.For more on a definition of history see Marwick (1989), Beddington (1979) and Tosh (2002) taught at public universities and then proceeded to show why history is vital for education today. I shall now discuss the importance of church history ${ }^{7}$ and what form it should take at the University and Faculty of Theology.

Gonzalez states that if Christianity is to be faithful to its vision of a single God, creator and sustainer of all that exists, that vision must be reflected in its own understanding of history - and not only of its own history, but of the entire history of God's creation' (Gonzalez 2002:100). He adds further that a church history whose concern is only the church and Christian believers, as if the rest of creation had nothing to do with the God of the church, is a pagan history! This does not mean that church history is not a distinct discipline, but it does mean that such history must never forget that it is part of a single and grand history that embraces much more than the narrow limits of the church. It is both within and beyond the church. In the case of history, the gospel must somehow relate to every dimension and every corner of human history.

Christians are increasingly aware that they no longer live in a Christian society - if they ever did, like in the Constantinian past. The society in which we live is pluralistic, multireligious and increasingly secular. Thus, church history cannot just focus on the history of the church but it must also seriously look at the history of the world in which the church is found. In this sense, it is part of general history but yet specific as it focuses on the history of the church.

Christian history includes a 'divine characteristic' (Paas 2000:12). It is a revelation of God's presence (Ibid, p. 14, see also Paas 2016) in the world, and it is heading towards a goal, the second coming of Jesus. It is a 'different genre of history with a distinctive goal, a theological meaning and a deep concern for people' (Kalu 2005:9). In this regard, it differs from general history, yet it has an obligation to collaborate with world history in so far as to what is happening in the world, primarily from the belief that this is God's world. Steven Paas (2000) affirms this view:

Church History is the human activity of researched, comprehensive and intelligible description of past deployments of the Church of God, in the midst of this world, in which men [sic] were involved through Jesus Christ by the power of the Word and the Spirits. (p. 12)

Taking it further, Kalu states that church history 'is not just the study of an Institution but also the process of interpreting history from a Christian standpoint. The essence of church history is to start with the assumption that the kingdom of God is present like leaven in human history and, in light of that, to study the complex process whereby societies have been transformed through time' (Kalu 2005:10).

In understanding this broad perspective of church history, Hofmyer and Pillay are quick to point out that church

7.I call this section "Historical Theology' because of the new name it will be given in the new Department. However, for now, I will continue to refer to the current name of the Department as Church History. 
history is 'the history of contextualisations of Christian understanding'. Kalu agrees with this in saying that church history is the 'story of the pilgrim people of God and their experiences of God's redeeming grace in the midst of their existence in various cultural and ecological contexts' (Kalu 2005:11).

Perhaps the value of church history and historical theology can be best summarised in the words of Gerrish: 'In a word, it is not the explication of authoritative dogmas, nor the exegesis and systematising of Scripture, but disciplined reflection on a historically given, historically mobile way of believing that matters (author's own italics)' (Gerrish 1993:248). The fact that church history is part of general history, and it is a reflection of what God has done and is doing in the world makes it a necessary discipline both in the Faculty of Theology and at the university.

\section{Historical theology within the Faculty of Theology}

The Faculty of Theology at the University of Pretoria is undergoing a restructuring process. A decision has been made to merge the Departments of Church History and Polity with Dogmatics and Ethics. The new Department, to be formed in 2019, would be called the Department of Systematic and Historical Theology. In a recent article entitled 'Historical Theology: Content, methodology and relevance', Dreyer and Pillay (2017) supported the change of name from Church History to Historical Theology but indicated very strongly that it must be seen as much more that a history of doctrine. They suggested that the term 'historical theology' should be used in a more generic sense, almost as an umbrella term, which would include various sub-disciplines such as history of doctrine and church history. Historical theology is not church history but they can certainly work together in the common purpose of getting to the truth. ${ }^{8}$ Schleiermacher puts it well: 'More exactly, dogmatics is classified as historical phenomenon the part, namely, that deals with the present state of the Christian community's beliefs. The past state of those beliefs is assigned to church history which is also a part of historical theology' (Gerrish, p. 263). In this sense, Schleiermacher could have hardly driven a wedge between dogmatic theology and history of Christianity.

Extracting from what I have said above about theology at a public university, I shall now discuss the implications of this at the university. Although what I offer here already describes what is being done, to some extent, in the Faculty of Theology, my focus is on church history. The current Department of Church History and Polity (and even the new Department) should have before it the following foci in its continued and future vision.

8.My reference here to 'getting to the truth' is drawn from Schleiermacher's und historical theor historica theology, and when he states that historical theology "coheres with science proper through philosophical theology' he cannot mean that church history and dogmatics are not sciences, he means that this is how they are sciences (Gerrish:264)

\section{Research and teaching}

UP has set five key strategic goals to becoming a leading university in Africa and the world at large. It is currently among the top 500 universities in the world and aims to improve its ranking position by at least 100 positions. Two of those five goals relate to research and teaching. They are (1) to be a research intensive university in Africa (goal 1) and (2) to pursue excellence in teaching and learning (goal 4) (see UP 2025 Plan).

As already mentioned, Johan Buitendag recently shared that modern day universities are beyond John Newman's idea of a university where research is done for the sake of research. Newman argued that knowledge is there for its own end and that the ideal of universal knowledge is the driving force of all research. In this sense, religious truth is not only an aspect but a condition of general knowledge. However, the driving forces of universities today, according to Buitendag, are basically three indicators: impact, reputation and funding (Buitendag 2017). These indicators, no doubt, have a significant impact on how we appreciate and view theology today, at least at universities. It also calls for theology to assume a greater concentration on research and teaching that is relevant, credible and publishable on various levels and fields to generate a pool of sustainable funding. Realising the changes in universities today and the goal of UP to be a 'research intensive university in Africa', it is important for the Department of Church History to encourage, motivate and strategically plan for research outputs from staff. I will say more about the focus of research and its relevance in the sections that follow. Here I simply wish to emphasise that a vision for the Department must include strong and solid research output, whilst also nurturing and developing the teaching and learning component.

The traditional approach to church history is to divide it into four periods (Early Church, Medieval Period, Reformation and Modern Period) and to describe the main events and personalities of a certain period (see Reventlow [2009] and McGrath [2013]). Instead of this traditional approach, Dreyer and Pillay (2017) have suggested that historical theology be structured and organised into seven subsections: introduction to historical theology, history of churches, history of theology, history of missions, public theology, church polity and ecumenical history. According to Vosloo (2009:56-57), such an approach would require a high level of specialisation in terms of research. However, it provides a thematic structure which enables a contextual approach to reading, understanding, interpreting and applying history.

Church history is not a subject that is hugely attractable because it gives the impression of learning about the past which can sometimes be dry and uninteresting. It has always been my objective when teaching this subject to make it alive and interesting. The way to achieve this is to look at the following steps in the preparations and delivery of lessons: context, interpretation, application and relevance. Further, the teaching methodologies employed in teaching must be 
re-examined. It must be engaging, interactive, inquiry-based, discovery-led and meaningfully applied to real life experiences and situations today. In our Department, we tend to avoid sit-down examinations; instead, we conduct oral exams and assignments. We believe that history is not about the regurgitation of facts but an attempt to learn from the past, understand the present and shape the future. Given the apartheid history of South Africa, it is important that we gather students in diverse groups to critically analyse the past and learn together from another's experiences. Particularly in the first year classes, opportunity must be used to bring students who have been separated for so long together. There is a need for transformation in the curricula, how we teach church history and what we teach has to be revisited with contextual and real-life experiences. As we teach church history, we should also continue to develop and expand on opportunities for blended, hybrid and e-learning. We must realise that we are not only studying history but making history as we analyse the present and shape the future. This leads me to the next point.

\section{Community engagement}

As we teach and research in the area of church history and polity, we must engage with participants within the community, such as religious leaders, pastors, academics, local congregants, denominations and a variety of other participants. Theology at the university can no longer be done in ivory towers. It has to serve both church and society. We have drawn a wedge between the pastor and theologian as if the one can succeed by not being the other. The perception that academic scholarship is abstract and 'theoretical', disconnected from the issues of daily life, neither relevant nor necessary for 'practical' ministry, is perhaps the single greatest prejudice against theological education (Van Hoozer \& Strachan 2015:5). The pastor theologian finds herself in a sort of no-person's-land between two worlds, at home in neither (Hiestand \& Wilson 2015:22). The laity in his congregation suspects he's wasting his time on theological mumbo jumbo that has no connection with real life, whereas at the same time, he is isolated vocationally and relationally from the scholarly resources of the academy (Ibid, p. 22).

This gap, however, is now getting bridged by the understanding that the pastor-theologian is a peculiar public figure (Ibid. p. 15). In this sense, there is the appeal for the recognition for public theology which is 'theology in and for the public square' (see Gavin D'Costa 2005, for a good explanation of this term). The pastor-theologian is involved with people in and for community. Theology thus must engage with reality and real-life struggles if it is to be real. We need to analyse and understand the socio-economic and political context and assess the role of the church in such a setting. We can reflect on similar issues in the past and be able to offer suggestions for the present in order to create a better future. What can we learn from the role of the church in the past? How can it be helpful to attend to understanding the present? How did the church address socio-political and economic issues in its time? How did it address immorality, corruption, poverty, justice, reconciliation, etc.?
In a recent article in the Weekend Argus (19 August 2017:19) entitled 'Young scientists ponder water crisis', it was reported that Young Scientists at the Cape Town Regional Eskom Expo presented solutions to the province's water crisis. Professor Susan Bourne of UCT's Department of Chemistry said at the opening of the Expo, 'It is fantastic to see young scientists paying attention to the things that society needs. If you ask the learners why they chose water conservation-related topics, you're likely to be met with a puzzled look and an answer along the lines of, 'because we're facing a water crisis'. For many pupils this topic is a no-brainer, because this is what these young scientists do best: they look at the problems their communities are facing and they find solutions to them'. This, too, is the purpose of theology as it engages with societal needs and challenges.

The vision is to direct the Department to teach and research in relevant and needed areas. This is in keeping with the vision of the Faculty of Theology: 'To be a faculty recognised for its creative engagement with life-giving theology and religious insight, of service to academia, church and community.' The Department of Church History and Polity has already included in its teaching curricula subjects and topics addressing gender issues, racism, environmental issues and social justice. In engaging with community issues, some of our research projects are related to the Sustainable Development Goals on poverty, justice, gender and African Christianity and development.

The focus would be to provide relevant theological and religious education, develop and nurture transformative leaders, undertake relevant quality research and engage with the marginalised, needy and poor people in society. Gonzalez calls for the inclusion of 'new voices', 'new questions' and 'younger churches' in the writing of church history (Gonzalez, Ibid, pp. 20-24). He points out that the interlocutors have changed so as to include more people of mixed race as well as more women; this means that church history is becoming much more interested in the daily life of Christians (Ibid, p. 25). The shifts have been enormous. Whereas in years past our most valued sources for study of church history were the writings of ecclesiastical leaders and the archaeological remains of churches and cathedrals, we are now making more use of documents and other sources that speak to us of everyday life. It is all about relevance and making a difference in the world in which we live.

\section{Interdisciplinary and trans-disciplinary collaboration}

Secularisation has also lead to the fragmentation of theology. Generally theology is divided into neat blocks of specified disciplines: basics, beliefs and practices. Whilst there is definitely a place for this, theologians would do well to encourage a cross-disciplinary conversation between the biblical studies scholar and the systematician, the church historian and the lecturer in apologetics. Theologians need to overcome their own internal boundaries and their isolationist mentality, rather promoting conversation, collaboration, and 
collegiality within the academy while also stimulating public debate in society as a whole. For example, if you are looking at the theme of poverty; church historians can examine the historical role of the churches addressing poverty, biblical scholars can reflect on poverty and wealth in the scriptures, practical theologians can ask what ministries the church can exercise to deal with poverty, systematic theology can look at a theology of the poor and missiology can reflect on mission with the poor.

Further, theology as a proper member of the academy possesses unique links to other fields of research, such as linguistics, history, philosophy, anthropology, and sociology, and this makes theology an essential integrative element at the university, encouraging the members of the different disciplines to communicate with one another and to engage in lively discussions (Graham, p. 116). Theology holding onto the view that all fields of research are united as they attempt to understand God's revelation in God's creation, in nature, and in history can play a very significant role promoting the ' $u n i$ ' in the uni-versity when the university is in danger of developing into a 'multi-versity' or 'di-versity'. As Professor de la Ray put it 'theology can help us (the university) to embrace diversity and empathy' (address at the opening of the Faculty in February 2016).

Speaking about church history in South Africa, Denis (1997:85) points to the fragmentation of South African church history: '[it] is an isolated discipline, almost completely cut off from the social science and from secular history in particular'. He considers it to be ecclesiocentric, with an Afrikaner and Dutch Reformed character. With regard to the academic world, Denis (1997:85) claims that 'church history appears as an isolated entity, inward-looking and insufficiently related to other disciplines which dealt with related subjects or with the same subjects but with different methodologies'.

In order to meet the above objectives, it is essential that there is collaboration between the different Departments in both teaching and research within the Faculty of Theology whereby together we engage on these relevant themes mentioned above. Although this is currently present, it must definitely increase in vision, proportion and practice. This is already evident in the Faculty's research theme on Ecodomy (life in its fullness). However, it would need to be implemented with intentionality and constant evaluation.

Further, if we are to meet the above objectives, it is necessary that Theology interacts with other disciplines at UP. The vision must be to motivate, encourage and foster a culture of cross-pollination of ideas, conversations, research and publications on a trans-disciplinary level. Church history needs to collaborate with other disciplines at the university other than theology. For example, as we address issues of poverty, economics, moral leadership, etc. we can do so with the other disciplines engaging in economics, development studies, history and art, etc. This would certainly impact on the quality of research we produce, which the theology faculty is committed to undertake. It is impossible to envisage this taking place except with very careful long-term institutional support. A vision for the Department is to develop and grow the interdisciplinary and trans-disciplinary output to enhance the quality of teaching and research at UP, which is also part of the strategic goals of the university (goals 1, 3 and 4).

\section{Nationalisation and internationalisation}

One of my first tasks when I became HoD was to connect with other Church History or its equivalent departments in South African universities. I attempted to look at their teaching and research programmes and identify best practices that can be implemented in the Church History Department at UP. The idea is to make the Department the most talked about one in South Africa with the hope that it would attract more students and postgraduate students in Church History. Our Department did not have a strong connection and networking with other such departments even though we have relationships with church historians from these institutions. My vision is to change this to make us a strongly recognised contributor in the field and to collaborate with other church historians in formulating and transforming the curriculum as per church history. I am already in conversations with other church historians about expanding and deepening our focus on African Christianity. My vision is to continue to develop our local networks and strength our participation with other such Departments. I would like to create access and opportunity for our postgraduate students to publish in reputable journals, encourage joint publications and books, research opportunities and other such possibilities to advance research and teaching.

Church history, as we pointed out earlier, has to be connected with world history. It looks at the history of the church as it is found in the world. This thought stimulates a very strong need for international relationships and collaboration. In my previous role as President of the World Communion of Reformed Churches I was able to establish connections with very prominent church historians and church history departments in Europe, US, Korea, Taiwan, Cuba, Africa and others. The intention is to pursue further communication with world recognised Church History Departments in various universities across the globe to learn from them, implement what is possible in our own Church History Department, and to enable UP to 'strengthen the university's international profile and visibility'. The vision is to facilitate student and staff exchanges, integrate postgraduate work, develop curriculum, external examinations, sabbaticals, collaborative research projects and opportunities, and publications in international journals.

\section{Africanisation}

One of the challenges that most educational institutions face in South Africa is the need to 'Africanise' the institutions. We tend to draw from Europe and the US failing to recognise and harness the rich experiences and learning opportunities from the African continent. Nadar points out that theologians are 
trained in a Western form of theologising but are unable to respond epistemologically adequately to social problems in a new context (Nadar 2007:239). It is thus not surprising that Balcomb states that in terms of theological education Africa needs to 'get in step with Christianity as an African religion at an epistemological level' (Balcomb 2014:72). Kombo calls for a break with the past and a focus on the African realities (2013:105). Maluleke (2006:71) establishes that unless Africans do theology in Africa its relevance would remain in question. Naidoo affirms this view:

It is the African who is and must be the primary and principle communicator of the African experience. Africanisation is a conscious and deliberate assertion of nothing more or less than the right to be African. (Naidoo 2016)

Graham Duncan reminds us that there is not one definition of African, and it needs to be defined by Africans themselves within their own context taking into account the massive diversity in Africa and the multiplicity of ways of being African' (Duncan 2000:73). Referring to contextual theologies, Maluleke (2015) suggests that theology needs to pay attention to African women theology, lack theology and liberation. All these themes are important for historical theology.

In fact, these theologies do not start from the conventional debates of 'paradigms', 'scientific revolutions', 'problem solving' and 'rationality' as does the Euro-American philosophy of science (Piet Naude 2015:238). African theology as an alternative system of thinking is not a theology of the book (Setiloane 1986:36) that shares Western scientific or philosophical sophistication $(28,45)$. It views Western theology as a threat to the 'soul of Africa' (44) and is in itself an attempt to express faith 'from the perspective of African grassroots, background and culture' (35). From this perspective 'knowledge' and 'rationality' are closely linked with an oral tradition (Setiloane 1986:1-2) and religious myths have an explanation normally reserved for natural science in the Western tradition (Koech 1977:118).

Liberation theologians, normally suspicious about the 'academic' character of Western theology (Miguez-Bonino 1975:XIX; Segundo in Hennely 1979: XII), tend to do a spontaneous reflection on the experiences of the poor in Latin America (Gutierrez 1983:76, 90). These new theologies provides a new epistemology to engage with social problems in order to change the way society exists (Beyers 2016:6).

Africanisation needs to occupy a top priority at the university and the Faculty of Theology. It should not be mere tokenism or window-dressing initiatives but an intentional effort of 'doing' theology from within the African context. In church history we have already included African, black and Liberation theologies in our modules. We continue to focus quite in-depth on African Christianity in our modules. However, all of these needs to be further integrated into a holistic approach which addresses the African context and yet speak globally to another context. Otherwise we would continue to be what Graham Duncan says 'UP retains the traditional Western reality of a theology faculty with a veneer of Africanisation' (2016:6). The new department must continue the initiatives of 'africanising' the curriculum with intentionality and responsibly.

\section{Transformation}

Many South African universities and learning institutions have been 'captured' by the apartheid ideology and practice. Since the liberation and democratisation of South Africa in 1994 these institutions are gradually seeking renewal and transformation, albeit at a slow pace in some places. The University of Pretoria was also an institution under apartheid capture, though some of its staff, notably from theology, challenged the system. However, the theology faculty is known to have supported the apartheid policy and even, through some of its church partners, justified apartheid. Even though the faculty is trying to redress the situation, its percentage of black academic and women staff is highly questionable in proportion to the demographics of South Africa.

As it currently stands, the Department of Church History and Church Polity is in need of further diversity and gender balances. My vision is to work with the current staff in the Department and the Faculty to implement a strategy that would address diversity and gender issues. My intentional plan is to recruit some female lecturers to include perspectives from women in church history. As pointed out earlier church history needs to include the 'voices' of the poor and marginalised not only in teaching content but also in the people who teach as well.

Denis (1997) speaking into the South African context states that historians:

tend to place more emphasis on the theological and ecclesiastical identity of their denominations than on others. This is inevitably characterised by a predominantly white disposition. It is mainly white voices that are heard in South African church or religious history, and it is also predominantly white documentation that feeds the archive from which history will develop in the future'. (p. 87)

Fortunately this has changed much since Denis' article but, it must still be worked on with vigilance. The Department of Church History and Polity needs to move from a confessional and ecclesial focus to embracing a more ecumenical outlook. This calls for transformation in the curricula and the way church history is thought, by whom and for whom?

\section{Interreligious collaboration}

The Faculty of Theology has taken the decision of changing its name to the Faculty of Theology and Religion as from January 2018 (see Faculty Plan 2016). The word 'religion' is a very important inclusion in this context of inclusivity and religious pluralism. But the question is 'how far do we plan to go with this?'

Edward Farley (1988:72) points out the challenge of adding 'religion' to theology. He states that if the objective is to have 
no religion behind the religions then there is no object of religious scholarship and teaching in any of these senses. It needs to be understood in a hermeneutical sense of the three principles of concreteness, experientiality, and reality, which in his words 'protects the integrity, distinctiveness, and seriousness of religion' (1988:73). He thus establishes that the aim would be to explore and teach specific historical religions, both at the level of knowledge about them and at the level of encounter with the claims they set, the insights they proffer. A second aim is to explore and teach the structural similarities of historical religions. And a third aim is to attempt to illumine religiousness itself, religion as an aspect of human existence (1988:72-73).

Volf (2015), referring to religion and globalisation, provides another significant reason as to why religions ought to work together, he states that world religions establish networks that connect people on the basis of shared visions of the good life across the globe:

[But] world religions do something even more momentous for the history of globalisation than inspire global mission and establish transcultural networks: all of them in their own way teach the fundamental unity of all humanity. (p. 38)

Global religions provide the kind of moral vision and have the potential to influence economics, politics, society and human behaviour. Religions have the ability to effect legislative and moral change:

They are neither the only nor the most creative agents of change around, and their track record is in many ways spotty. But as vibrant, growing, and politically assertive global communities with memberships constituting three-quarters of the world population, world religions have the power, motivation, and infrastructure for effective global engagement. (Volf 2015:57-58)

The university provides an ideal environment for enabling different religions to work together for the common good of society.

Returning to the question of 'how far do we go'? The tendency in most universities today is to go the way of forming a Religious Studies Department. However, this is quite different from a Faculty of Theology at the university. The report on the Quality Assurance of Netherlands Universities (QANU 2012) stated the following about the place of theology at a university:

It is important for theology to be present in secular universities. It has a very positive role to play in providing reflective enquiry into fundamental questions of human nature and existence, and in exploring the approaches to those questions with one or more major and historically crucial religious traditions. Theology has therefore to be conserved as an autonomous discipline with its own theory-building and methodology, independently of the external approach of religion by religious studies and of its more instrumental use for ministerial training, and also irrespective of the commitment to church policies (p. 9)

Adding my view to this, I would say that since Christianity is moving to the Global South, the majority of people in Africa profess to be Christians, and theology is well established as an academic discipline, it should remain at public universities as theology. At UP, the Faculty of Theology has essentially developed from a confessional and ecclesial point of departure, and still is, in its current form. However, it needs to steadily move into a more ecumenical form. Ecumenical organisations provide a space for interreligious dialogue and engagement. They consider it important in addressing the realities of the world in the midst of huge global challenges. They thus find it easier to enter into mutual trust and engagement on issues. The goal is not conversion but conversation. This approach would greatly enhance and stimulate broad and relevant research.

A faculty that is based on confessional and ecclesial leanings may find it more difficult to embrace a relationship of mutual trust and engagement with other religions. Some churches may even find it unacceptable and contaminating to be found in the company of other religions, let alone to work side by side in a university environment. Those who hold on to the exclusive claims that only Christianity is the true and superior religion, afraid of syncretistic tendencies, and interpret scripture from a narrow Christocentric perspective normally fit into this category.

The inclusion of religion with theology at the university is not an 'unholy alliance' but a stimulation of 'holy conversations' as the different religions attempt to understand, work and collaborate with one another. This allows for good research and scholarship, exchange of ideas and possibilities of tackling the world's challenges together, especially in the height of religious fundamentalism and violence. We need to recognise that Christianity is not the only religion in the world and the sense of Christendom has long passed. Worst still, with increasing secularisation the world does not necessary enjoy the 'sacred canopy' everywhere (D'Costa 2005:2).

Church history has a very important role to play in this as we study the history of other religions, trace the historical relationships of Christianity alongside these religions and assess the impact of working in relationships towards the building of the one human family. Historical theology needs to examine the history of theologies of other religions, such as, Islam, Hinduism, African traditional Religions, and Judaism. This has to be more than comparative religions, which is usually assigned to Science of Religion and Missiology; it has to get into the depth of historical roots, formation, development and understanding, all with the objective of building the one human family. The new Department, in conjunction, with other departments in the Faculty and disciplines at the university needs to give greater attention to interreligious engagement.

\section{Conclusion}

In this article I have argued that church history or historical theology matters at public universities. I have shown this by indicating that theology matters in public universities by 
asking some significant questions related to: the purpose of the university, the purpose of theology, the value of history, and the role of church history or historical theology. Most significantly, I pointed out that whilst church history matters in public universities, it must take into serious consideration the need for relevant teaching, learning and research, community engagement, interdisciplinary and transdisciplinary research, nationalisation and internationalisation, Africanisation, transformation and interreligious relations.

In the final analysis, what matters is not so much the history of theology but the theology of history. It is applying the 'God question' in all of life and asking, inquiring, and participating in what God is doing in the world. Of course, this only matters to people and institutions that believe that God matters. In a world that is $80 \%$ religious, and in the continent of Africa where over $90 \%$ are religious, and largely Christian, it is imperative that theology matters in public universities but it is also important to note that whilst we may preserve the distinctive identity of Christian theology, we cannot do theology in an exclusively Christian way. We need to open the 'gates' to include the given realities of today because today matters in the shaping and building of our tomorrows, our history!

\section{Acknowledgements Competing interests}

The author declares that he has no financial or personal relationships which may have inappropriately influenced him in writing this article.

\section{References}

Avis, P., 2003, Church drawing near: Spirituality and mission in a post-Christian culture T\&T Clark International, London.

Balcomb, A.O., 2014, 'Shifting the theological paradigm in Africa-building on the legacy of Kwame Bediako', in G.M. Bediako, B.Y. Quarshie \& J.K. Asamoah-Gyadu (eds.), Seeing new facets of the diamond: Christianity as a universal faith, pp. 67-80, Regnum, Oxford.

Barth, K., 1975, Fides quaerens intellectum: Anselm's proof of the existence of God in the context of his theological scheme, Pickwick (Pittsburg Reprint Series), Pittsburgh.

Beddington, D., 1979, Patterns in history, a Christian perspective on historical thought, Apollos, Leicester.

Beyers, J., 2016, 'Theology and higher education: The place of a faculty of theology at a South African university', HTS Teologiese Studies/Theological Studies 72(4), a3450. https://doi.org/10.4102/hts.v7214.3450

Brautigam, M., 2015, 'A Queen without a throne? Harnack, Schlatter, and Kuyper on theology in the University', in G. Graham (ed.), The Kuyper Center review, volume five: Church and academy, William B. Eerdmans Publishing Company, Grand Rapids, MI.

Buitendag, J., 2017, 'The idea of the university and the "Pretoria Model": Apologia pro statu Facultatis Theologia Universitas Pretoriensis ad secundum saeculum" Verbum et Ecclesia, forthcoming.

D'Costa, G., 2005, Challenges in contemporary theology: Theology in the public square, Church, Academy and Nation, Blackwell Publishing, Australia.

Denis, P., 1997, 'From church history to religious history: Strengths and weaknesses of South African religious historiography', Journal of Theology for South Africa 99, 84-93.

Department of Basic Education, 2011, Curriculum and Assessment Policy Statement Grades 10-12, p. 8, viewed 20 August 2017, from http://www.education.gov.za/ LinkClick.aspx?fileticket=F99lepqD6vs $\% 3 d \&$ tabid $=570 \&$ mid $=1558$

Dreyer, W. \& Pillay, J., 2017, Historical theology: Content, methodology and relevance, Verbum et Ecclesia, forthcoming.

Duncan, G.A., 2000, 'Theological education: Mission birth - African renaissance', Missionalia 28(1), 23-40.

Duncan, G.A., 2016, 'Gateway to the future ... oopmaak van die hekke Transformation in the faculty of theology, University of Pretoria', HTS Teologiese Studies/Theological Studies 72(4), a3424. https://doi.org/10.4102/hts.v72i4.342
Farley, E., 1988, The fragility of knowledge: Theological education in the Church \& the University, Fortress Press, Philadelphia, PA.

Gadamer, H.G., 1975, Truth and method, Sheed and Ward, London.

Gerrish, B.A., 1993, Continuing the Reformation: Essays on Modern Religious Thought, The University of Chicago Press, US.

Graham, G., 2015, The Kuyper center review, volume five: Church and academy, William B. Eerdmans Publishing Company, Grand Rapids, MI.

Griffin, D. \& Hough, J., 1991, Theology and the university: Essays in honor of John B. Cobb, Jr. State University of New York Press, New York.

Gonzalez, J.L., 2002, The changing shape of Church history, Chalice Press, St Louis, MO.

Gutierrez, G., 1983, The power of the poor in history, SCM, London.

Hennely, A.T., 1979, Theologies in conflict: The challenge of Juan Luis Segundo, Orbis, New York.

Hiestand, G. \& Wilson, T., 2015, The pastor theologian: Resurrecting an ancient vision, Zondervan, Grand Rapids, MI.

Jonker, W.D., 1976a, 'What is Theology?', in P.C. Schrotenboer (ed.), Church and theology in the contemporary world, Grand Rapids, MI.

Kalu, O.U., 2005, African Christianity, an African story, Department of Church History, Pretoria.

Koech, K., 1977, 'African mythology: A key to understanding African religion', in N. Booth (ed.), African religions: A symposium, pp. 117-139, NOK Publishers, New York.

Kombo, J., 2013, 'The past and the presence of Christian theology in Africa universities', in I.A. Phiri \& D. Werner (eds.), Handbook of theological education in Africa, pp. 100-107, Regnum Books, Oxford.

Kung, H. \& Tracy, D., 1989, Paradigm change in theology: A symposium for the future, Crossroad, New York.

Kuyper, A., 1998, 'Sphere sovereignty', in J.D. Bratt (ed.), Abraham Kuyper: A centennia reader, Eerdmans, Grand Rapids, MI.

Lombaard, C., 2011, 'Having faith in the university? Aspects of the relationship between religion and the university', in R. Venter (ed.), Faith, religion and the public university, pp. 49-65, Acta Theologia Supplementum 14, UFS-UV, Free State.

Louth, A., 2004, 'Theology, contemplation and the university', Studies in Christian Ethics 17(1), 69-79. https://doi.org/10.1177/095394680401700105

Mante, J.O.Y., 2017, 'Theology in Public Universities in Africa', Papers presented at the Centenary Celebrations Colloquium, 'Reimagining Curricula for a Just University in a Vibrant Democracy: Carry the Conversation Forward', University of Pretoria, pp. 31-37.

Maluleke, T.S., 2006, 'The Africanisation of theological education: Does theological education equip you to help your sister?', in E.P. Antonio (ed.), Inculturation and postcolonial discourse in African theology, pp. 46-55, Peter Laing Publishing, New York.

Maluleke, T.S., 2015, All tertiary education hurdles must fall, Mail \& Guardian, 6 November, viewed 23 August 2017, from http://mg.co.za/article/2015-11-07-alltertiary-education-hurdles-must-fall

Marty, M.E., 1989, 'The social context of the modern paradigm in theology: A church historian's view', in H. Kung \& D. Tracy (eds.), Paradigm change in theology: $A$ symposium for the future, Crossroad, New York.

Marwick, A., 1989, The nature of history, 3rd edn., Macmillan, Basingstoke.

McGrath, A.E., 2013, Reformation thought: An introduction, 4th edn., Blackwell Publishing, Oxford.

Miguez, B.J., 1975, Doing theology in a revolutionary situation, Fortress, Philadelphia, PA.

Ministry of Education, 2000, Report of the history/Archaeology panel to the minister of education, Department of Education, Pretoria, viewed n.d., from http://www. gov.za/documents/report-historyarchaeology-panel-minister-education

Nadar, S., 2017, 'Contextual theological education in Africa and the challenge of globalisation,' The Ecumeical Review 59(2-3), 235-241. https://doi. org/10.1111/j.1758-6623.2007.tb00630.x

Naidoo, M., 2016, 'Overcoming alienation in Africanising theological education', HTS Teologiese Studies 72(1), Art. \#3062, 1-8. https://doi.org/10.4102/hts.V72i1.3062

Naude, P., 2015, Pathways in theology: Ecumenical, African and Reformed, Sun Media, Stellenbosch.

Newman, J.H., 1982, The idea of a university, University of Notre Dame Press, Notre Dame, IN.

Norris, P. \& Inglehart, R., 2004, Sacred and secular: Religion and politics worldwide, Cambridge University Press, Cambridge, UK.

Oden, T.C., 1979, Agenda for theology, Harper \& Row Publishers, Grand Rapids, MI.

Oden, T.C., 1992, Agenda for theology after modernity what? Zondervan Publishing House, Grand Rapids, MI.

Paas, S., 2000, Digging out the Ancestral Church, researching and communicating church history, Nlantyne, Clain.

Paas, S., 2016, Christianity in Eurafrica: A history of the church in Europe and Africa, Christian Literature Fund, Wellington.

Peel, D., 2002, Reforming theology, The United Reformed Church, London.

Phiri, I.A. \& Nadar, S., 2011, “"The personal is political”: Faith and religion in a public university', in R. Venter (ed.), Faith, religion and the public university, pp. 81-94, Acta Theologia Supplementum 14, UFS-UV, Free State.

Quality Assurance Netherlands Universities (QANU) Report, 2012, Research selfevaluation of the Faculty of Theology (2005-2011), VU Univesity, Amsterdam. 
Reventlow, H., 2009, History of biblical interpretation, in S. Ackerman \& T. Thatcher (eds.), vols. 1-IV transI. LG Perdue, Society of Biblical Literature (SBL), Atlanta, GA.

Setiloane, G.M., 1986, African theology. An introduction, Skotaville, Johannesburg.

Speech made in Parliament. Bekezela Phakathi, Department working on making history compulsory at school, BD LIVE, 6 May 2015, viewed 23 August 2017, from http://ww.bdlive.co.za/national/education/2015/05/06/department-workingon-making-history-compulsory-at-school

Tappan, H., 1961, 'Idea of the True University', in R. Hofstadter \& W. Smith (eds.) American higher education: A documentary history, p. 517, vol. 2, University of Chicago Press, Chicago, IL.

Tosh, J., 2002, The pursuit of history: Aims, methods and new directions in the study of modern history, rev. 3rd edn., Longman, London.
Van Hoozer, K. \& Strachan, O., 2015, The Pastor as public theologian: Reclaiming a lost vision, Baker Academic, Grand Rapids, MI.

Van Niekerk, A., 2011, 'Understanding theology as understanding', in R. Venter (ed.), Acta Theologica Supplementum 14, University of the Free State, Free State.

Volf, M., 2015, Flourishing: Why we need religion in a globalized world, Integrated Publishing Solutions, Grand Rapids, MI.

Vosloo, R., 2009, 'Quo vadis church history? Some theses on the future of church history as an academic theological discipline', Scriptura 100, 54-64. https://doi. org/10.7833/100-0-653

Webster, J., 2003, Current issues in theology: Holy scripture a dogmatic sketch, Cambridge University Press, Cambridge, UK.

Willis, D. \& Welker, M., 1999, Toward the future of reformed theology: Tasks, topics, traditions, William B. Eerdmans Publishing Company, Grand Rapids, MI. 